gest, as Gilmore seems to do, that the Cassinuses and Strephons are irredeemable; that their redemption is even beyond God's powers; that Swift is mocking them only for the fun of seeing them squirm (or if they are too insensible even to squirm, of inviting the rest of us to enjoy the spectacle of their absurdity and resulting misery); that he would feel the "desirability" of their redemption to be "dubious" (presumably as detracting from the fun of the spectacle) is to make Swift a sadistic monster. In fact, of course, Gilmore, at the end of his essay, refutes what he says, or seems to say, here. If Swift "never tires" of recommending good sense, then he is presumably recommending it to the Cassinuses and Strephons of this world. Why should he waste his time doing so if the recommendation is "utterly impracticable"? This is to make Swift considerably less than a practitioner of "good sense" himself.

Gilmore usefully insists that the reference to "gaudy Tulips" at the end of The Lady's Dressing Room is "distinctly ironic" (p. 40). The gaudy Celia, like other things in this imperfect world, is considerably less than the perfection of beauty. But wouldn't Gilmore (and Swift) agree that, esthetically, she is at least some improvement over "dung"?

\section{Donald Greene}

University of Southern California

\section{To the Editor:}

Thomas B. Gilmore, Jr., in "The Comedy of Swift's Scatological Poems," has called needed attention to the comic aspects of these poems and provided significant new insights through his detailed close readings of them. Useful as his analysis is, I must express two reservations about his methods and conclusions.

The first reservation is that this is simply more of the same old New Criticism, treating the poems as objects created by an idealized poet fully in control of himself and his art, a well-balanced, judicious Swift with a "settled distaste for all romantic unreality." Maurice Johnson urged critics several years ago to begin considering Swift's personal involvement in his poems: "his own identity and his poetry seem inseparable" ("Swift's Poetry Reconsidered," English Writers of the Eighteenth Century, ed. John M. Middendorf, New York: Columbia Univ. Press, 1971, p. 240). For no other of Swift's poems is there greater need to consider the poet together with his work than for the scatological poems. Other writers (Rabelais, Dryden, Pope, the novelists later in the century) have used scatology, but not so often as Swift or with such intensity. The recurrence and vehemence indicate a certain uneasiness, like an adolescent's preoccupation with sex. Swift protesteth too much, and that protesting becomes an involuntary part of the meaning and effect of the poems. I am not advocating a return to psycho- analytic criticism-there simply is not enough reliable data to make such an exercise worthwhile. But I am maintaining that purely objective criticism will not do for works that give so much evidence of personal involvement by the poet. It creates artificial structures and themes which, in the end, lead to misunderstanding of the poems and of the author.

My second reservation concerns the failure to distinguish between comic elements and comic tone. The poems do have comic elements; that Swift intended them to be comic works seems very likely. Unless the comic elements are unified by a fairly consistent comic tone, however, the poems may not be comic on the whole and surely cannot be "comic masterpieces." Of the five poems Gilmore discusses, only Cassinus and Peter sustains its comic tone evenly enough to be deemed wholly successful; significantly, its presentation is detached, consisting mostly of dialogue. The other scatological poems are less detached and less successful. Swift may very well have intended $\boldsymbol{A}$ Beautiful Young Nymph as a comedy of exposure, and parts of it (11. 1-28, 57-70) work very well. But other lines-"Her Shankers, Issues, running Sores" (1. 30), "With Pains of Love tormented lies" (1. 39), and "faintly screams" (1. 42), for example produce a sympathetic response in any sensitive reader and do not fit with the comic parts. What comedy there is is certainly "harsh comedy," as Gilmore says, but too much of the poem is not comedy at all. Readers have responded to the poem in such various ways because Swift was unable to unify the poem and elicit a single effect.

The Lady's Dressing Room in all likelihood was intended to describe a comic situation; the use of climax in the central scene and the allusive similes (11. 69-118) are indeed effective in doing so. But the lists and details early in the poem are too intense in tone to match the lightness of the latter part. The sounds in the lines convey a harshness that is not "dispassionate, almost tolerant," as Gilmore contends. Listen, for example, to "Allum Flower to stop the Steams, / Exhal'd from sour unsavoury Streams" (1I. 27-28), or "Fowl'd with the Scouring of her Hands" (1. 38), or "Begumm'd, bematter"d, and beslim"d" (1. 45). The choice and arrangement of words and sounds are, of course, Swift's, not a persona's, and their effect is definitely not the "training laughter" Gilmore hears. Something besides comedy is going on here. Deeper feelings of the author are showing through and, by working against the comedy, they detract from the successfulness of the poem.

Had Strephon and Chloe ended at line 218, it would have been a successful, light comic piece, using contrasts between the literary and the real, the figurative and the literal, nicely to create a meaningful humorous situation. But the final 96 lines of heavy-handed ser- 
monizing destroy the unity and. by not letting the situation speak for itself, the effectiveness of the poem. The attitude displayed in the final section is not consistent with the "quiet ... good sense" Gilmore finds in the poems as a group, or with the "calm attitude toward filth" he ascribes to Swift himself. Swift, in line 253 , calls defecation a "Blemish" which, decency requires, must be hidden: he reiterates this in lines 307-14. where "Decency" is called the cement that holds a friendship together. A man must, in other words. be aware that women do have such a "natural Defect" (1. 274). but women must take great care that men are never contronted by it: wives, especially: "should study to be clean; / Nor give the smallest Room to guess/ The Time when Wants of Nature press" (Il. 138 40). Swift did, after all, build two outhouses at Market Hill so that "In sep'rate Cells the He's and She's" may "pay their Vows" to Cloacine (A Paneg.rick on the Dean, II. 207-08; my italics) - and one might venture a guess that he made sure no crannies were left in either.

The poems, then, give considerable evidence that Swift was not entirely at ease with his subject. The very frequency with which he returns to it, in prose and verse, suggests that he did not so readily accept "waste as a natural part of life" as Gilmore concludes. Tone, repetition. sound, and word choice are an essential dimension of each poem and they provide hints regarding Swift's personal attitude which must not be overlooked. As Swift's attempts at playfulness are foiled by passages of squeamishness or near revulsion, we see not a Swift who has it all together, with answers to every question embodied in polished, sophisticated art. That is a Swift of twentieth-century making. Rather, the scatological poems show us a more human Swift, fallible, uncertain, struggling - trying to work through his feelings, but not succeeding entirely. The scatological poems give us, in the end, the most intimate glimpse into himself that Swift ever permitted.

\section{Peter J. Schakel \\ Hope College}

\section{Mr. Gilmore replies:}

In spite of Donald Greene's claim that our essays read Swift's scatological poems in much the same way. I believe that both Donald Greene's essay and his comment disclose fundamental differences between us in approach and emphasis. Although there are some parallels in our awareness of Swift's comic perceptions. Greene's primary concern is obviously with the satiric aims and effects of the comedy. This concern, indeed, seems so overriding in his comment that it very nearly leads him to imply that Swift could or would write no other kind of comedy. But even if the distinctions in my essay between satiric and nonsatiric comedy are not al- ways as sharp as they might have been, I should have thought it clear that I was focusing mainly on comedy that requires minimal attention to satire: on Swift's playful allusiveness, his juxtaposed incongruities, his at times calm attitudes toward his characters" discoveries in contrast with their near hysteria. Of course. I hope my essay demonstrated that appreciating such comedy :an be separated to a substantial degree from awareness of Swift's moral values as Christian clergyman and lrom knowledge of the classical and Renaissance theories of comic satire with which he was familiar. But why does Greene insist that even if this separation is possible, it is a deplorable error? Behind his apparent and reasonable request that Swift's satiric and nonsatiric comedy be given at least equal weight. I suspect Greene is only reiterating what has become established dogma: that recognition of Swift's moral aims and values must always take critical priority. My essay proceeded from the assumption that these aims and values had already been made so plain, by Greene and quite a few others. that yet another extended look at them could only have further contributed to the one-sidedness I sought to provide a corrective for.

Admittedly, the line in Swift's poems between nonsatiric and satiric comedy is not always easy or even desirable to draw. It is more a matter of the emphasis one chooses than of clear subgeneric difierence; many or most of the comic effects which can be isolated and relished for their own sakes also have satiric and moral ends. Certainly I would not deny, and did not in my essay. that Strephon and Cassinus may be tools of didactic satire. I balk at Greene's contention, however. that Swift would have been a "sadistic monster" to ridicule them without somehow acknowledging the possibility of their amendment. This view takes the two characters much too seriously and also seems naive about the connection between the satiric theory Swift undoubtedly knew and his actual practice as a satirist. The only evidence of this connection Greene submits, a couplet from Verses on the Death of Dr. Swift, is shaky; Greene surely knows that more than one critic has been unable to swallow most of the section in which this couplet appears as unqualified truth. Moreover, wat Pope, who knew the same satiric theory, irresponsible or "sadistic" for satirizing numerous blockheads in the Epistle to Dr. Arbuthnot even though in the same poem he states three different times (11. 83-84, 89-90, 95-100) that he regards them as incorrigible? Or has any reader of the poem seriously believed that Pope thought Lord Hervey might reform as a result of the Sporus portrait?

Greene seems to be on more tenable ground when he maintains that Strephon and Cassinus have exemplary value: they "will not change, since they have no existence outside the poems," but they may furnish a timely warning or antidote to "some young people, prey to delusions like" theirs. Here at least are a 